\title{
Economic valuation of sport fisheries in Los Cabos, Baja California Sur, Mexico
}

\author{
I. Gómez ${ }^{1}$, A. Ivanova ${ }^{1}$, G. Ponce ${ }^{2} \&$ M. Ángeles ${ }^{1}$ \\ ${ }^{1}$ Academic Department of Economics, \\ Autonomous University of Baja California Sur, Mexico \\ ${ }^{2}$ Fisheries Department, \\ Interdisciplinary Center for Marine Science, Mexico
}

\begin{abstract}
Sport fishing is one of the main tourist attractions in Baja California Sur (BCS), with a multiplier effect with impacts on three sectors of its economy. There is, however, a growing confrontation between those interests that represent the sport fishing sector, and those involved in commercial fisheries, whose activities often include the capture of species reserved for the former, either by means of permits or "accidentally." In addition, before the research which is reported in this paper, there was no methodologically sound estimate of the economic value of sport fisheries. This was estimated by the cost of travel method, which attempts to determine the number of journeys/visits to a given recreational site per period of time, usually a year. This involved the application of a survey (220 questionnaires, of which 133 were usable) in the area of Cabo del Este, BCS, in order to generate the data needed to estimate the relevant demand function (number of visits as a function of travel cost), its inverse, and average and total consumer's surplus. Using information available at the Los Cabos municipality, which gives the figure of 40,000 sport fishing visitors per year, we estimate the economic value of this activity in that area at about US $\$ 72$ million.

Keywords: economic value, travel cost method, consumer surplus, sport fishing, demand curve.
\end{abstract}

\section{Introduction}

Sport fisheries are amongst the main tourist attractions, and hence employment and foreign exchange sources, in the Gulf of California and Baja California Sur 
(BCS), owing to the extraordinary richness and variety of species of interest in those waters. Tourist expenditures on this activity result in multiplier effects on three sectors of the BCS economy: tourism itself, fisheries, and manufacturing, SEPESCA [1]. CONAPESCA, the National Agriculture and Fisheries Commission, estimates that the value of the state's sport fisheries from direct payment to boat operators and other expenses stood at US \$79 million in 2006, CONAPESCA [2]. However, a 2007 report by the Billfish Foundation dealing with the employment and tax revenue effects of sports fishing in the Los Cabos area (BCS's main tourism destination), gave the figure of US $\$ 1,125$ million as the estimated total impact of this activity. Clearly there is much uncertainty in these measurements and, in the latter case, a huge overstatement.

Sport fisheries in Mexico are regulated by the Mexican Official Norm (NOM) 017-PESC-1994, DOF [3], which specifies the equipment that may be used, and the size and amount of the catch by species. The limit is ten specimens a day for each fisherman, and not more than five of any particular species. With marlin, swordfish, sailfish, and shark, the limit is one per day per fisherman, as each organism is taken to be equivalent to five of other species. In regard to mahimahi (dolphin fish), shad, and rooster fish, the limit is two, with a similar equivalence as in the previous case.

Sport fishing may fit well with the concept of environmental sustainability, as its impact on fishing resources, when properly managed, can be smaller and less intense than that of other fisheries, owing to its selective nature (although it is also vulnerable to overfishing). According to CONAPESCA, the main source of tension in BCS is the exploitation by commercial fisheries of species deemed exclusive to sport activities. Such competition has led to conflict about what the proper resource management is to be - and for whose benefit. The sport fisheries sector, closely linked with tourism interests, has claimed that billfish captures by commercial fisheries lead to a reduction in the number of visitors (mostly foreigners) to the main fishing and tourist areas. As mentioned, they also claim that sport fisheries generate very large economic benefits, such as cannot be matched by commercial alternatives, if account is taken of visitor expenditures on lodging, food and drink, boat rental, and other services, CONAPESCA [4].

The tension between these two coastal activities in BCS has intensified since the Federal government's introduction of NOM 029, which was meant to regulate shark and ray fishing. Commercial fishermen are reported to be selling marlin, swordfish, and sailfish and registering their catches as shark, thus effectively "legalizing" them. Some studies show a 30 per cent fall in shark populations, but fishing volumes have remained high owing to the black market in bill species (Villavicencio [5]). The tourism sector is unhappy with the terms of established by NOM 029, since that norm allows commercial boats to fish for shark within the 50 nautical mile limit set for sports fisheries, thus allowing them to "accidentally" capture reserved species.

Given the importance of sport fisheries for the BCS economy, and that of economic valuation for efficient resource allocation, the main objective of this paper is to estimate the economic value of those fisheries, so as to allow the 
correct measurement of the benefits associated with that activity. Travel cost is taken to be the relevant valuation method.

Accordingly, the paper is divided as follows. After this introduction, in section 1 we summarise our valuation methodology, survey design and sample size. Results are given in section 2, which is followed by our conclusions.

\section{Methodology}

\subsection{The travel cost method}

The estimation of travel costs by means of surveys is one of the most frequently used methods for estimating the economic value of recreational activities when well-defined markets do not exist, as is the case with sport fisheries (Huschmidt et al. [6]; Freeman [7]; Winpenny [8]). The travel cost method depends on the assumption that even when access to public recreation sites has zero cost, visitors pay an implicit "price" for the site's services. This implicit price includes payment for private goods, such as the cost of transport and travel time (i.e., its opportunity cost), and is considered to be analogous to an entry price. The diversity of visitor provenance is assumed to provide information sufficient to estimate the demand function for the site and its services, where the number of visits is associated with the cost of travel (Smith et al. [9]). The method is based on neo-classical welfare theory.

Cost of travel methods attempt to estimate the number of visits to a given site during a specified time period or season. Surveys are used to gather data on travel costs and other relevant variables, which are then employed to predict the number of visits to the site. The relevant demand curve is estimated by an ordinary least squares (OLS) regression equation, with the number of visits per year as the dependent variable and travel cost as the independent variable, OECD [10]. This can yield individual (average) consumer surplus which, when multiplied by the number of visits per time period, gives total consumer surplus (defined as the benefits received and perceived by the buyers (Varian [11]). In our case, we obtain an estimate of the total recreational value of sport fishing in BCS (Christensson [12]) from the standpoint of the visitors.

\subsection{Sample size determination}

A pilot survey involving 47 sport fishermen was conducted, which was a useful starting point for the main survey, as it allowed us to form a first impression about the characteristics of the general population. Additionally, the pilot survey was used to estimate the variance of the variables, and hence to estimate sample size at the 0.05 level of significance, which gave a 95 per cent confidence estimate that the mean value of those variables could be correctly calculated.

The size of the sample required in order to obtain confidence intervals of 95 per cent is given as follows: age. 26 questionnaires; income, 55; visits, 15; and total expenditure, 21 . Given these requirements, 55 questionnaires were applied, so as to ensure that an adequate confidence level was attained. 


\subsection{The Cabo del Este area}

Even though the paper's objective is to estimate the value of sport fisheries in BCS as a whole, surveys were applied only in the Cabo del Este area, which was taken to represent the state. The rationale was that this area has not been much studied, even though it is of great (and growing) importance for that activity. A further reason behind the choice of the area to be studied was that other fishing spots lack a single meeting point (i.e., a wharf) whence fishermen gather before taking to sea (Ditton et al. [13]). An additional point should be noted: only user values are considered, so what this paper reports is the value of the fishery to sport fishermen only, given that they obtain the direct utility.

Cabo del Este is located about $120 \mathrm{~km}$. south of La Paz (the state capital). The area includes the communities of Punta Pescadero, Los Barriles, Buenavista, La Rivera, Cabo Pulmo and Los Frailes. Over the past three decades, the area has become a sport-fisherman's paradise owing to the abundance of marlin, swordfish, sailfish, tuna, mahi-mahi, and snapper. The area is frequented by visitors coming from diverse points in the United States, which means that quite different travel costs are involved.

\subsection{Survey design and implementation}

The questionnaire employed consists of 25 items, four of which are meant to ascertain purpose of visit, yearly frequency, and the importance of fishing in the decision to visit the area. There follow 14 questions that seek to investigate in greater depth the interviewee's characteristics: sport-fishing experience, reasons for choosing a particular boat, species captured, and type of license obtained, among others. Finally, a seven-question section was included so as to capture the respondent's personal and socioeconomic characteristics: nationality, annual income, age, and education level, as well as travel and hotel costs and total expenses.

A face-to-face approach was employed, asking interviewees to fill out a questionnaire after each question was explained. In all, 220 questionnaires were given out; on average, about 80 per cent of questions were answered, with some differences on which had no reply. After a close examination of the questionnaires, 133 (which yielded a total of 390 visits) were found to be usable, and these were later employed in the estimation of the relevant demand equation. The survey was conducted in 2010 at four different dates: May, June, July and August.

\section{Results}

\subsection{Estimation of the demand curve}

The results of the survey were used to estimate a well-behaved (i.e., downwardsloping) relationship between number of visits and travel cost. Market demand was obtained by aggregation of individual demands at given prices (travel costs), 
and results were in accordance with microeconomic theory, as visits fell as costs increased.

It should be noted that travel costs refer not only to actual (direct) disbursements such as airplane fares, hotel, and food and beverages expenses, but also include opportunity cost, defined as that which the person chooses not to have when the decision is made to have something else. Opportunity cost is here measured as the amount of time spent in travelling to and from the fishing grounds plus actual fishing time, and the converting this into lost income by using an estimate of daily income derived from the survey. As Christensson [12], has remarked, this assumes that individuals substitute income for time. Although several methods are available for making the relevant transformation, we have used the definition of opportunity cost given by Seller et al. [14]:

$$
O C=(Y+W / 2080) * \text { Time }
$$

where OC is opportunity cost; $\mathrm{Y}$, average annual income, $\mathrm{W}$, a conversion factor that maps working time into leisure (generally 0.25. 0.33, or 0.50; we use the middle value); 2080, the number of hours theoretically worked in a year (i.e., 8 hours per week during 52 weeks); and Time, the number of working hours spent in the fishing area, weighted by the eight-hour working day. Thus opportunity cost is represented by a percentage of income (Freeman [7]).

Price (cost of travel) and quantity (number of visits) are then plugged into an econometric model in order to derive the demand curve for sport fishing, with visits as the dependent and travel cost as the independent variables. A semilogarithmic equation is used, following Ziemer et al. [15], Adamowicz et al. [16], all cited in Chávez [17], as this is the preferred form in the literature on the travel cost method.

In fact, once the dispersion of the data was examined, it was confirmed that the semi-log form of the regression equation (visits in linear form and travel cost in semi/log form) gave the best fit, showing the highest value for $R^{2}$. Our OLS equation, estimated by using the E-Views econometric package, version 5.0, is the equation (2):

$$
\text { Visits }=-3.36 \ln (\text { cost })+390.19, \quad R^{2}=0.8267
$$

The model is globally significant, as the F-value (57.23) exceeds any value of $\mathrm{F}$ at any level of significance, with one degree of freedom in the numerator and 12 in the denominator. We can thus reject the null hypothesis that those parameters are equal to zero, either jointly or simultaneously. The value of $R^{2}$ implies that 82.87 per cent of the variation in the number of visits is associated with the cost of travel, as defined above. In the same vein, the value of R (-0.9092) signifies that there is a strong correlation between the dependent and the independent variables. Finally, the Durbin-Watson statistic (d) was used to test for first order serial autocorrelation (Gujarati [18]). As in our case the value of $d$ was approximately equal to 2 , we concluded that there was no 
autocorrelation of that sort. As expected, a negative relationship was found between number of visits and travel cost.

In the semi-log model, the slope coefficient $\left(\beta_{2}\right)$, is interpreted as follows (Gujarati [18]): the absolute change in $\mathrm{Y}(\Delta Y)$ equals the slope multiplied by the relative change in $\mathrm{X}$. For example, if travel cost $\left(\frac{\Delta X}{X}\right)$ rises by 10 per cent, with $\beta_{2}$ equal to -43.46 , the absolute change in visits is given by $(0.10)(-43.36)=4.34$; that is, a 10 per cent increase in travel cost results in a fall of (about) 4 visits per year.

Given a 95 per cent confidence interval and 13 degrees of freedom for $\beta_{1}$, we may conclude that the probability that the true value of that coefficient is between 287 and 494 is equal to 0.95 . Otherwise put, in the long run 95 per cent of values of $\beta_{1}$ (the equation's constant) will be found in the 287-494 interval (additionally, the given interval confirms that the value of $\beta_{1}$ is not zero).By a similar procedure, $\beta_{2}$, (the coefficient associated with the demand equation's independent variable, has a 95 per cent probability of falling in the -31 to -56 interval (additionally, $\beta_{2}$ is non-zero).

\subsection{Consumer's surplus}

The estimation of consumer's surplus allows that of the user value of sport fishing, since that value is determined by the utility of the goods or services in question, that is to say, their capacity to satisfy an individual's needs or desires (in our case, the desire to capture billfish in BCS). The calculation of consumer's surplus necessitates knowledge of the inverse demand function, since by convention price variables are shown on the $\mathrm{y}$ axis, i.e., what is commonly graphed is not the demand function, but its inverse. From a mathematical standpoint, of course, this difference is not of great significance.

Conventional economic analysis is simplified by assuming that prices are market-determined, that is, that they are set jointly by demand and supply, so that for each individual they are a given. Thus, from the demand curve estimated in the previous section we can derive the inverse demand, eqn. (3):

$$
\text { Cost }=7.237 .4 e^{-0.019 v i s i t s}, R^{2}=0.8267
$$

From eqn. (4), it can be shown that the consumer's surplus (CS) is given by:

$$
C S=\int_{0}^{28}\left[7,237.4 e^{-0.019 q}-3,155\right] d q
$$

where cost $=p$, visits $=q$, and the average number of visits of the 133 questionnaires $\left(q_{0}\right)=28$, and their cost $\left(p_{0}\right)=\mathrm{US} \$ 3,155$. Solving the equation, we find that total consumer's surplus for 133 visitors is US\$68,625, so that individual consumer surplus is equal to US \$ 517. Since the number of fishing trips to the Los Cabos municipality is reported to be about 40,000, and since our survey yielded an average of 3.5 fishermen per trip, we estimate the average yearly value of sport fisheries in Los Cabos at US \$72,447,303. Further research is needed to relate these findings with the sustainability of the fishery. 


\section{Conclusions}

The state of Baja California Sur (BCS), Mexico, depends crucially on tourism for its economic development efforts, and the Los Cabos municipality is BCS's main tourist destination. Sport fishing is a key activity in the Los Cabos, but is beset by acute tensions with the commercial fisheries sector, which often impinges (legally or not) on what the former considers to be its exclusive rights. Despite its importance, until now there has been no methodologically sound investigation of the economic value of sports fisheries in the state. The research here reported seeks to remedy this situation. We use the travel cost valuation method of environmental economics, derived from neoclassical welfare theory.

We conducted a survey in the Cabo del Este area of BCS, which elicited 133 usable responses. The data thus generated were used to estimate a demand equation (visits as a function of travel cost), its inverse, and average and total consumer's surplus. This information allowed us to estimate the value of sport fishing in the municipality of Los Cabos at about \$72 million. This finding is a step toward the rigorous evaluation of the sustainability of sport fishing in BCS.

\section{References}

[1] SEPESCA, Secretaría de Pesca, Fomento y modernización de la pesca deportivo-recreativa. Secretaría de Pesca, 63 p. 1991.

[2] CONAPESCA, Comisión Nacional de Pesca (CONAPESCA). Secretaría de Agricultura, Ganadería, Desarrollo Rural, Pesca y Alimentación (SAGARPA), 2008.

[3] DOF. Diario Oficial de la Federación. Norma Oficial Mexicana NOM-017pesc-1994. Para regular las Actividades de Pesca Recreativa en la Aguas de Jurisdicción Federal de los Estados Unidos Mexicanos. Vols. No. 15-19. México, D.F. 1995.

[4] CONAPESCA, Comisión Nacional de Pesca. Secretaría de Agricultura, Ganadería, Desarrollo Rural, Pesca y Alimentación (SAGARPA). Plan De Acción: Estrategia Integral Para El Desarrollo De La Pesca Deportiva. Unidad de Enlace para el Desarrollo de la Pesca Deportiva. 83 p. 2004 http://www.conapesca.sagarpa.gob.mx/

[5] Villavicencio Garayzar C., http://www.elsudcaliforniano.com.mx. (07 de Mayo de 2008). 2007.

[6] Huschmidt, M.M, James D.J., Meister A.D., Bower B.T. and Dixon J.A., Environment, Natural Systems and Development. John Hopkins University Press, London, 327 pp., 1983.

[7] Freeman, A.M., The Measurement of Environmental and Resource Values: Theory and Methods. Resources for the Future, Washington D.C. 503 pp., 1993.

[8] Winpenny J.T., Values for the Environment: A Guide to Economic Appraisal. London HMSO, 277 p., 1991. 
[9] Smith V.K., Desvousges W.H., and Fisher A., A comparison of direct and indirect methods for estimating environmental benefits, American Journal Agricultural Economics, 68 (2): 280-290. 1986.

[10] OECD, Organization for Economic Co-operation and Development, Handbook of Biodiversity Valuation. A Guide for Policy Makers. Paris, 2002.

[11] Varian H., Microeconomía Intermedia. Un enfoque actual. Quinta edición. Antoni Bosch Editor. Barcelona, España. 726 p. 1999.

[12] Christensson, A., An economic Valuation of the Coral Reefs at Phi-Phi Island: AT travel Cost Approach. Master's thesis, Lulea University of Technology, Sweden, 55 pp. 2003.

[13] Ditton R.B, Grimes S. R, and Finkelstein, L.D., A social and economic study of the recreational billfish fishery in the Southern Baja Region of Mexico. Report for the Billfish Foundation, Ft. Lauderdale Florida, 45 p. 1996.

[14] Seller, C., Stoll J.R., and Chavas, J.P., Validation of empirical measures of welfare change: A comparison of nonmarket techniques. Land Economics, 61 (2): 156-175.1985.

[15] Ziemer, R.F., W. N. Musser and Hill R.C. Recreation demand equations: functional form and consumer surplus. Amer. J. Agric. Econ. 62: 136141. 1980.

[16] Adamowicz, W.L., Fletcher, J.J. and Graham-Tomasi, T.Functional form and statistical properties of welfare measures. American Journal Agricultural Economics 71 (2): 414-421. 1989.

[17] Chávez Comparan J., Importancia económica de los beneficios generados por la pesca deportiva en Manzanillo, Colima, México. Doctoral dissertation, Universidad Autónoma de Baja California. Ensenada, B.C. (Mexico), 134 pp. 2001.

[18] Gujarati, D., Econometría, McGraw-Hill Interamericana, Santa Fé de Bogotá, Colombia. 2004. 